Gitation: González-Maldonado, J., Muñoz-García, C., Serna-Lagunes, R., Salazar-Ortiz, J., Gallegos-Sánchez, J.,\& Cortez-Romero, C. (2021). Reproductive management in whitetailed deer (Odocoileus virginianus Zimmermann). Agro Productividad. https://doi.org/10.32854/agrop. v14i8.2063.

Editor in Chief: Dr. Jorge Cadena Iñiguez

Received: February 14, 2021. Accepted: August 17, 2021.

Published on-line: October 12, 2021

This work is licensed under a Creative Commons Attribution-NonCommercial 4.0 International license.

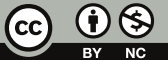

\title{
Reproductive management in white-tailed deer (Odocoileus virginianus Zimmermann)
}

\author{
González-Maldonado, Juan ${ }^{1,2}$; Muñoz-García, Canuto ${ }^{1}$; Serna-Lagunes, Ricardo ${ }^{3}$; \\ Salazar-Ortiz, Juan ${ }^{4}$; Gallegos-Sánchez, Jaime ${ }^{1}$; Cortez-Romero, César ${ }^{1,5, *}$ \\ ${ }^{1}$ Colegio de Postgraduados Campus Montecillo. Carretera México-Texcoco km. 36.5, Montecillo, Texcoco, \\ Estado de México, México. C. P. 56230. \\ 2 Universidad Autónoma de Baja California. Instituto de Ciencias Agrícolas. Carretera a Delta S/N, Ejido \\ Nuevo León, Mexicali, Baja California, México. C. P. 21705. \\ 3 Universidad Veracruzana. Facultad de Ciencias Biológicas y Agropecuarias, Zona Orizaba-Córdoba. \\ Carretera Peñuela-Amatlán de los Reyes S/N, Peñuela, Amatlán de los Reyes, Veracruz, México. C. P. \\ 94953. \\ 4 Colegio de Postgraduados Campus Córdoba. Carretera Córdoba-Veracruz km. 348, Manuel León, Amatlán \\ de los Reyes, Veracruz, México. C. P. 94953. \\ 5 Colegio de Postgraduados Campus San Luis Potosí. Iturbide No. 73, Gentro, Salinas de Hidalgo, San Luis \\ Potosí, México. C. P. 78600. \\ * Correspondence: ccortez@colpos.mx
}

\section{ABSTRACT}

Objective: To review information related with the reproductive physiology and management of white-tailed deer for reproductive specialists and producers.

Design/methodology/approach: The information presented in this document relies on the review of scientific papers and on experience gained in white-tail deer production systems.

Results: White-tailed deer is a species with seasonal reproduction and one of the most important hunting species in Mexico. Currently, all reproductive biotechnologies applied to small ruminants can be used in whitetailed deer.

Limitations of the study/implications: Information regard the physiology and reproductive management of white-tailed deer is limited, probably due to conditions specific to its production system.

Findings/conclusions: Research and publication of information regard the physiology and reproductive management of white-tailed deer is needed.

Key words: hunting; physiology, biotechnologies, ruminant.

\section{INTRODUCTION}

The white-tailed deer (Figure 1) naturally distributes throughout most of the Mexican territory and is perhaps the most important hunting species of interest in the country (SEMARNAT, 2014). According to the CONABIO

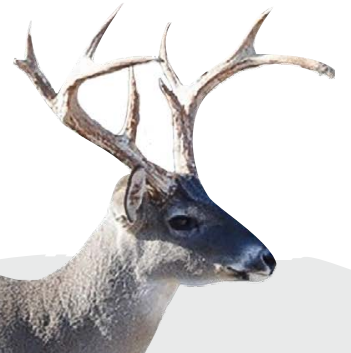
report (2012), of the 365 species registered for wildlife management units for conservation and exploitation (UMA) in the wild, white-tailed deer was registered in $86 \%$ of them. This indicates the economic and social importance of this species in Mexico.

In the white-tail deer production units, it is necessary to perform reproductive management practices to increase the probability of births of fawns at the desired time and with adequate characteristics. Currently, most reproductive biotechnology used in sheep and goats can be adapted to deer, yet it is important to know the general aspects of the reproductive physiology of the species, as well as its 


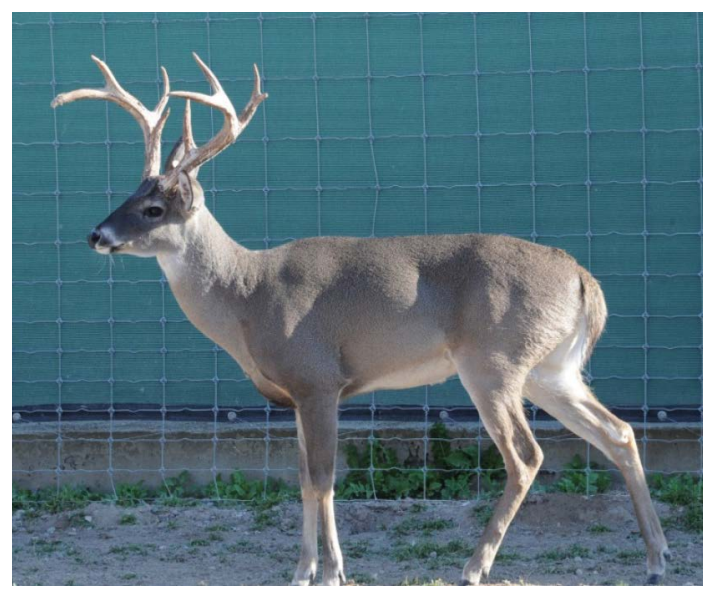

Figure 1. Male white-tailed deer specimen.

management within the production system. The objective of this document is to describe basic aspects of the physiology and reproductive management of white-tail deer.

\section{Seasonality}

The availability of forage for both wild and domestic ruminants vary throughout the year. Regarding this situation, white-tail deer have adaptive strategies for the efficient use of food availability, since the last third of gestation and lactation demand large amounts of nutrients (Osborn et al., 2000). Therefore, the number of offspring per parturition will depend on the quantity and nutritional quality of the consumed diet by the females; if the diet is nutritionally poor, females will only procreate one offspring, but if the diet is adequate and abundant, she will have two or more fawns (Ramírez, 2004).

Female white-tail deer are seasonal polyestrous and in both temperate and warm climates, they begin their reproductive activity in autumn and give birth by summer (Harder and Moorhead, 1980), when food is most available (DelGiudice et al., 2007; Asher, 2011). It is important to note that there is little or no information about the births of this species in its native warm environment, although there are studies that indicate that this species shows strictly seasonal birth patterns (Yamauchi \& Matsuura, 2009; Asher, 2011). Changes in the photoperiod in temperate climate are neuroendocrine signals to initiate or stop reproductive activity (Jacobson, 2007). In contrast, in the warm climate, deer are not exposed to a well-defined photoperiod, so their reproductive patterns evolved as a response to factors such as seasonal fluctuations in food availability, local competition for forage resources with other wildlife species, predation pressure, and variations in climate (Asher, 2011).

Changes in photoperiod or day length are sensed by the retina and suprachiasmatic nucleus of the deer, and are measured through the neurochemical secretion of melatonin, which is secreted during the night. It is a neuroendocrine signal that activates the reproductive axis in the short-day season, but inhibits it in the long days (Ebling, 2010). The greater exposure to melatonin secretion on short days decrease the sensitivity of the hypothalamus to the negative feedback of estradiol (hormone responsible for seasonality 
reproduction), which allows an increase in the pulsatile secretion of gonadotropin-releasing hormone $(\mathrm{GnRH})$ to activate the reproductive axis (Yamauchi and Matsuura, 2009); contrary to the case when deer are exposed to long days (Malpaux et al., 1996).

During the reproductive season, females exhibit estrous behavior, luteal progesterone secretion ( $\geq 1 \mathrm{ng} \mathrm{mL}^{-1}$ a level considered indicative of ovulation), conception rate through natural mating higher than $85 \%$ and reduced early embryonic mortality. In contrast, during anestrus, deer have low plasma progesterone concentrations (on average $<0.06 \mathrm{ng}$ $\left.\mathrm{mL}^{-1}\right)$, this is indicative of a complete cessation of ovarian activity and can last from 4 to 6 months, from spring to early fall (Harder and Moorhead, 1980).

\section{Puberty}

White-tail deer undergo pubertal changes prior to puberty onset. These changes are observed in secondary sexual characteristics and reproductive anatomy. In males, there is an increase in body size, neck bulging, development of calcified and hardened antlers during their first winter and appearance of velvet on them due to the production of testosterone; the rubbing of the antlers is the signal to start reproduction. The anatomical changes in the male's reproductive system are characterized by an increase in the secondary sex glands, the testicles and the epididymis. In females, changes in reproductive characteristics are less obvious than in males. Puberty may begin as early as six months of age, which depends on the food availability and quality. It is believed that up to $80 \%$ of fawns can conceive during their first year of life. But if food availability is limited or of poor nutritional quality, puberty is delayed by about one year. As in other cervid species, nutrition, especially energy intake and protein, plays an important role in the onset of puberty in females, since for this physiological process to begin, they must have an adequate body size to start reproducing (Jacobson, 2007).

\section{Estrous cycle}

The estrous cycle of the female white-tail deer (Figure 2) has an average duration of 26 days, and varies from 21 to 30 days (Knox et al., 1988). Estrus occurs on day zero of the cycle, a stage in which females accepts male's mating and last $39 \mathrm{~h}$ on average (Verme \& Ozoga, 1981). The female's receptivity at estrus is the result of the increase in estradiol concentrations coming from the preovulatory follicle(s); concentrations increase five days before estrus and reach their highest peak on the estrus day, which coincides with the preovulatory peak of luteinizing hormone (LH; Plotka et al., 1980). During this period, the females may copulate with more than one sire, resulting in offspring from different parents (DeYoung et al., 2002).

Ovulation occurs between 12 and $14 \mathrm{~h}$ after the end of estrus (Verme \& Ozoga, 1981). Females ovulate between 1.22 to 2.18 oocytes, with higher ovulatory rate in adult females than in young females (Ransom, 1967), with 1.88 offspring on average and mating services that can be between 25-96 h after estrus (Verme \& Ozoga, 1981). Following ovulation, the hormonal environment previously dominated by estradiol disappears with the rupture of a preovulatory follicle, giving way to the formation of the corpus luteum (CL) and its respective production of progesterone. Luteal progesterone is responsible for gestation 


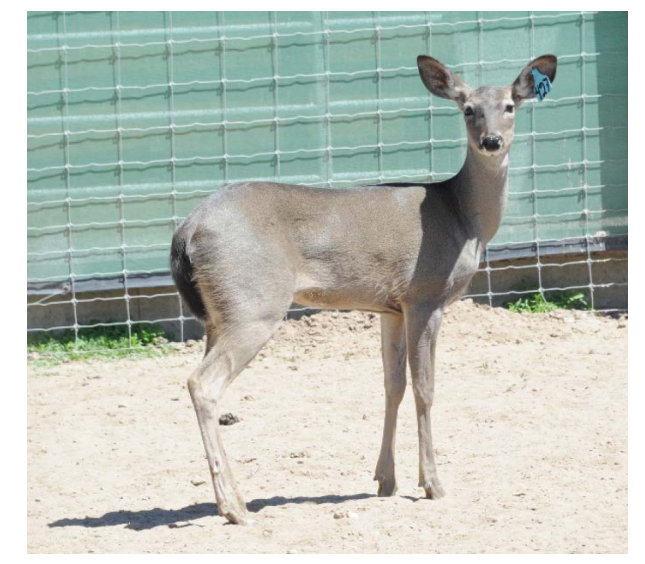

Figure 2. White-tail deer female specimen.

maintenance, at least until day 156 (Plotka et al., 1982). The production of this hormone progressively increases after ovulation. However, if the female does not become pregnant after inseminated or mated, these steroid concentrations begin to decrease seven days before the next estrus (Plotka et al., 1980).

\section{Manipulation of the estrous cycle}

The main objective of the estrous cycle manipulation is to control the onset of estrus at the most convenient time. For cattle, sheep and goats, the control of estrus onset as well as the use of artificial insemination (AI) have allowed controlling the productive development of herds and its genetic improvement. However, reports on the reproductive physiology, estrus synchronization and $\mathrm{AI}$ in white-tail deer females are scarce, despite their importance for hunting.

The basis for the estrus manipulation onset is to create a luteal phase, followed by a follicular phase, accompanied by a decrease in progesterone concentrations and an increase in estradiol concentrations from a developing follicle. The luteal phase can be simulated by insertion of a progesterone-releasing intravaginal device (PIDR), progesterone implants or sponges. Progesterone-releasing intravaginal device insertion has the advantage that it can be used at any time of the year, but their cost is a limitation. The intravaginal device can be applied for a period of seven (Gentry et al., 2007) or 14 days (Mellado et al., 2013).

In sheep and goats, it is common to administer equine chorionic gonadotropin (eCG) to females before or at the time of removal of the intravaginal device or progestogen, to increase the ovulation rate, as well as the synchrony of the onset of estrus after the device is removed. However, the application of $200 \mathrm{IU}$ of eCG in white-tail deer females has not yielded satisfactory results (Gentry et al., 2012; Haslag et al., 2016), suggesting the need for studies to evaluate the optimal dose of this hormone. Using the progesterone implant (Norgestomet) is carried out by placing only half of the implant in the animal's ear for 14 days (Willard et al., 2002). According to Randel et al. (1998), between 75 and 80\% of deer synchronized with the intravaginal device or implant will show estrus at approximately $58 \mathrm{~h}$ after progestogen withdrawal. 
Also, prostaglandin injection is used for estrus induction; although it is a cheaper method, it is only effective during the reproductive season, when regression of the existing GL is achieved to induce the onset of a new estrus or terminate an unwanted gestation. The used prostaglandin dose should cautiously be chosen, since the doses that cause regression of the CL and termination of gestation in cattle and goats are not effective in white-tail deer females (Becker \& Katz, 1994). In terms of estrus induction, satisfactory results have been obtained with the application of prostaglandin on day 11 of the estrous cycle (Magyar et al., 1989). According to Magyar et al. (1992), the effectiveness of prostaglandin injection in estrous induction is of $60 \%$.

Oestrus detection is commonly performed by repeated introduction of vasectomized males. During estrus, females remain immobile, with their ears folded back accepting males mounting, some females even adopt this position when handlers place their hand on the animal's rump. When performing the estrus check, care should be taken, as some males can be violent with females not in estrus or the staff (Warren et al., 1978). Females that are not in estrus, quickly move away from males and urinate more frequently, being more tolerant to the presence of the male $24 \mathrm{~h}$ before estrus (Gasset et al., 1998).

Once estrus presence of is guaranteed, on one side, groups of females are placed to be mounted by a stallion in a specific time; a strategy to obtain a harvest of fawns at the most desirable time of the year. Randel et al. (1998), with a ratio of 10 synchronized females per sire, obtaining a conception rate of $70 \%$ at the first service, higher than the $55 \%$ obtained in non-synchronized females. On the other hand, the AI of females, performed either by transcervical insemination with frozen semen in a range of 0 to $30 \mathrm{~h}$ after estrus detection (with 67 to $73 \%$ of gestations; 1989; Magyar et al., 1989) or by fixed-insemination time (60 $\mathrm{h}$ after removal of the intravaginal device) by transcervical route (with 24 and $56 \%$ of gestations, Gentry et al., 2007; Lambe et al., 2009). Willard et al. (2002) reported that semen deposition can be performed in the uterus body via trans-vaginal route, using an insemination applicator or the Gourley endoscope in 92 and 100\% of cases.

\section{Gestation}

High fertility tends to be a common characteristic of several cervids and specifically for female white-tail deer, fecundity is strongly influenced by habitat and the nutritional quality of the consumed food. Few studies have been conducted on this physiological stage, but it has been reported that the average duration of gestation is 200 days, with a 187 to 222 days variation (Ramírez, 2004). After fertilization, the embryo reaches the uterus 5 to 6.5 days after ovulation. Embryo implantation occurs shortly before day 27 post-ovulation. It has been established that the presence of a normal half-life CL for progesterone production is a major requirement for successful gestation (Harder \& Moorhead, 1980).

To prevent lysis of the CL, the embryo secretes a molecule called interferon tau, which suppresses oxytocin and prostaglandins release, resulting in maternal recognition of gestation (Asher et al., 2007). Fawn weight appears to be the main factor that triggers birth; however, the timing of birth slightly varies from year to year, depending on the conception timing and maternal nutrition (Heffelfinger, 2006). The number of offspring as well as 
their sex depends on the age and nutrition of the mother; usually one-year-old females have only one fawn per parturition, two-year-old females average 1.3 to 1.6 fawns, and females over three years of age have 1.5 to 1.8 fawns per parturition (full reproductive age; Jacobson, 2007; Gentry et al., 2012; Figure 3).

Gestation may be altered by nutritional factors; females with poor nutrition, slightly increase gestation length, are more likely to have low birth weight offspring, abortion or simply abandon their young after birth, compared to well-fed females (Ramirez, 2004). As parturition approaches, the females separate from the rest of the group and looks for a suitable place to give birth. After birth, the mother leaves the fawns in a safe place, returning to see them only two or three times a day. When calving twins, the fawns are usually separated at different resting sites to reduce the likelihood of predator attack on both (Heffelfinger, 2006). Deer milk contains twice as many nutrients as cow's milk, which provides the young with the necessary nutrients for a rapid development. After a few weeks, fawns begin to consume green forage, and in the first two months of life begin to move around with their mother. Weaning occurs at between two and four months of age (Jacobson, 2007).

\section{GONGLUSIONS}

The economic and hunting importance of white-tail deer (Odocoileus virginianus) in Mexico and the lack of information related to aspects of the physiology and reproductive management of this species, highlights the need to investigate, generate knowledge and disseminate the experiences that may arise from studies and field work with white-tail deer, in order to facilitate the application of reproductive biotechnologies.

\section{REFERENGES}

Asher, G.W. (2011). Reproductive cycles of deer. Animal Reproduction Science, 124, 170-175. https://doi. org/10.1016/j.anireprosci.2010.08.026

Asher, W.G., Haigh, J.G. \& Wilson, P.R. (2007). Chapter 127 - Reproductive Behavior of Red Deer and Wapiti, In Current Therapy in Large Animal Theriogenology (Second Edition), edited by Robert S. Youngquist and Walter R. Threlfall, W.B. Saunders, Saint Louis, pp. 937-942.

Becker, E.S. \& Katz S.L. (1994). Effects of exogenous prostaglandin-F2 (PGF2) on pregnancy status in whitetailed deer. Zoobiology, 13, 315-323. https://doi.org/10.1002/zoo.1430130405

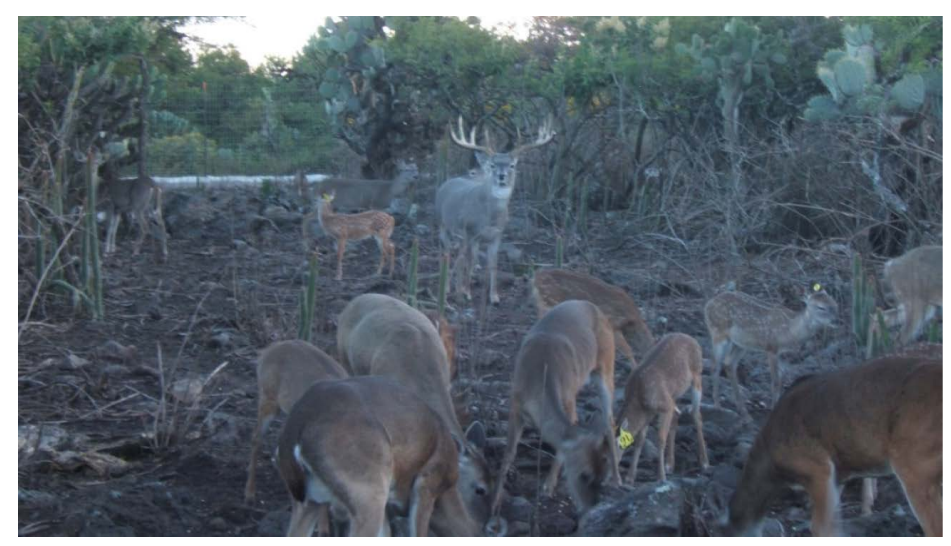

Figure 3. Female white-tail deer specimens with their fawns. 
Bubenik, A.G., Schams, D. \& Sempere, A.J. (1987). Assessment of the sexual and antler potential of the male white-tailed deer (Odocoileus virginianus) by GnRH stimulation test. Comparative Biochememestry and Physiology, 86(4), 767-771. https://doi.org/10.1016/0300-9629(87)90639-6

CONABIO (Comisión Nacional para el Conocimiento y Uso de la Biodiversidad). (2012). Proyecto de Evaluación de las Unidades de Manejo para la Conservación de la Vida Silvestre (UMA) (1997-2008). Resultados de la Fase I: Gestión y Administración. Proyectos CONABIO: HV003, HV004, HV007, HV012 y HV019. México.

DelGiudice, D.G., Lenarz, S.M., \& Carstensen, P.M. (2007). Age-specific fertility and fecundity in northern free-ranging white-tailed deer: evidence for reproductive senescence? Journal of Mammalogy, 88, 427435. https://doi.org/10.1644/06-MAMM-A-164R.1

DeYoung, W.R., Demarais, S., Gonzales, A.R., Honeycutt, L.R., \& Gee, L.K. (2002). Multiple paternity in white-tailed deer (Odocoileus virginianus) revealed by DNA microsatellites. Journal of Mammalogy, 83, 884-892. https://doi.org/10.1644/1545-1542(2002)083<0884:MPIWTD>2.0.CO;2

Ebling, P.J.F. (2010). Photoperiodic regulation of puberty in seasonal species. Molecular and Cellular Endocrinology, 324, 95-101. https://doi.org/10.1016/j.mce.2010.03.018

Gassett,J.W., Osborn, D.A., Rickard, J.K., Marchinton, R.L., \& Miller, K.V. (1998). Stimuli-related variation in urination frequency of female white-tailed deer during the estrous cycle. Applied Animal Behavior Science, 56, 71-75. https://doi.org/10.1016/S0168-1591(97)00055-5

Gentry, G.T. Jr, Saenz, J., Forbes, W., Whitehead, K., Sanders, D., Olcott, B., Chenevert, J., Bondioli, K.R., \& Godke, R.A. (2007). Pregnancy rates after using the cidr-g device and fixed-timed artificial insemination in white-tail deer. Reproduction, Fertility and Development, 20, 160-160. https://doi. org/10.1071/RDv20n1Ab160

Gentry, G.T., Lambe, J., Forbes, W., Olcott, B., Sanders, D., Bondioli, K., \& Godke, R.A. (2012). The effect of equine chorionic gonadotropin (eCG) on pregnancy rates of white-tailed deer following fixed-timed artificial insemination. Theriogenology, 77, 1894-1899. https://doi.org/10.1016/j. theriogenology.2012.01.007

Harder, D.J., \& Moorhead, L.D. (1980). Development of corpora luteal and plasma progesterone levels associated with the onset of the breeding season in white-tailed deer (Odocoileus virginianus). Biology of Reproduction, 22, 185-191. https://doi.org/10.1095/biolreprod22.2.185

Haslag, W.M., Shanks, B.C., Caldwell, J.D., Hill, D. R., \& Forsythe, N.L. (2016). Effects of PMSG dosage on reproductive performance of farm-raised whitetail deer. American Dairy Science Association. Proceedings of the meeting ADSA-ASAS, Des Moines, LA, USA. https://doi.org/10.2527/ msasas2016-417

Heffelfinger,J. (2006). Deer of the Southwest: A complete guide to the natural history, biology, and management of southwestern mule deer and white-tailed deer. College Station, US: Texas A\&M University Press. ProQuest ebrary.

Jacobson, A.H. (2007). Chapter 130: Reproductive Management of White-Tailed Deer. In: Current Therapy in Large Animal Theriogenology (Second Edition), edited by Robert S. Youngquist and Walter R. Threlfall, W.B. Saunders, Saint Louis, pp. 965-969.

Knox, MW., Miller, V.K., \& Marchinton, R.L. (1988). Recurrent Estrous Cycles in White-Tailed Deer. Journal of Mammalogy, 69, 384-386. https://doi.org/10.2307/1381395

Lambe, J., Forbes, W., Olcott, B.M., Sanders, D.E., Godke, R.A., \& Gentry, G.T. (2009). Effect of GnRH on fixed-timed artificial insemination pregnancy rates of white-tailed deer. Reproduction Fertility and Development, 22, 170-170. https://doi.org/10.1071/RDv22n1Ab24

Magyar, S.J., Biediger, T., Hodges, C., Kraemer, D.C., \& Seager, S.W. (1989). A method of artificial insemination in captive White-tailed deer (Odocoileus virginianus). Theriogenology, 31, 1075-1079. https:// doi.org/10.1016/0093-691x(89)90491-3

Magyar, S.J., Hodges, G.M., \& Kraemer, D.C. (1992). Synchronization and Superovulation in Captive WhiteTailed Deer. The Biology of Deer. Springer New York, USA.

Malpaux, B., Viguié, G., Skinner, D.C., Thiéry, J.C., Pelletier, J., \& Chemineau, P. (1996). Seasonal breeding in sheep: Mechanism of action of melatonin. Animal Reproduction Science, 42, 109- 117. https://doi. org/10.1016/0378-4320(96)01505-9

Mellado, M., Orta, G.G., Lozano, E.A., García, J.E., Veliz, F.G., \& de Santiago, A. (2013). Factors affecting reproductive performance of white-tailed deer subjected to fixed-time artificial insemination or natural mating. Reproduction Fertility and Development, 25, 581-586. https://doi.org/10.1071/RD12055

Osborn, A.D., Gassett, J.W., Miller, K.V., \& Lance, W.R. (2000). Out-of-season breeding of captive whitetailed deer. Theriogenology, 54, 611-619. https://doi.org/10.1016/S0093-691X(00)00376-9 
Plotka, E.D., Seal, U.S., Verme, L.J., \& Ozoga, J.J. (1980). Reproductive steroids in deer. III. Luteinizing hormone, estradiol and progesterone around estrus. Biology of Reproduction, 22, 576-581. https://doi. org/10.1093/biolreprod/22.3.576

Plotka, E.D., Seal, U.S., Verme, L.J., \& Ozoga, J.J. (1982). Reproductive steroids in white-tailed deer. IV. Origin of progesterone during pregnancy. Biology of Reproduction, 26, 258-262. https://doi.org/10.1095/ biolreprod26.2.258

Ramírez, L.R.G. (2004). Nutrición del venado cola blanca. Coeditado por la Universidad Autónoma de Nuevo León (UANL), Unión Ganadera Regional de N.L. y Fundación Produce N.L.A.C. Monterrey, Nuevo León, México. pp. 240.

Randel, D.R., Kroll, C.J, Smalling, J.A., Sellers, D.J., \& Koerth, H.B. (1998). Infusing new genes: natural or artificial insemination? Proceedings of the role of genetics in white-tailed deer management $2^{\text {nd }}$ Edition. Texas A\&M University, USA.

Ransom, B. (1967). Reproductive biology of white-tailed deer in Manitoba. The Journal of Wildlife Management, 31, 114-123. https://doi.org/10.2307/3798366

SEMARNAT (Secretaría del Medio Ambiente y Recursos Naturales). (2014). Plan de manejo tipo para la conservación y aprovechamiento sustentable del venado cola blanca (Odocoileus virginianus) en climas templados y tropicales de México extensivo y cría en cautiverio.

Verme, J.L., \& Ozoga, J.J. (1981). Sex ratio of white-tailed deer and the estrus cycle. The Journal of Wildlife Management, 45, 710-715. https://doi.org/10.2307/3808704

Warren, R.J., Vogelsang, R.W., Kirkpatrick, R.L., \& Scanlon, P.F. (1978). Reproductive behaviour of captive white-tailed deer. Animal Behavior, 26, 179-183. https://doi.org/10.1016/0003-3472(78)90017-9

Willard, S.T., Neuendorff D.A., Lewis, A.W., \& Randel, R.D. (2002). A comparison of transvaginal artificial insemination procedures for use in commercially farmed deer. Small Ruminant Research, 44, 135-140. https://doi.org/10.1016/S0921-4488(02)00048-2

Yamauchi, K., \& Matsuura, Y. (2009). Endocrinology of sika deer. Biology and management of native and introduced populations. Editorial Springer, pp. 83-99. 